\title{
The Development Trend of Higher Vocational Education in Developed Countries and Regions and Enlightenment on China
}

\author{
Yidong Sun \\ Linyi University Feixian Campus, Shandong province, China
}

Keywords: higher vocational education; development trend; enlightenment.

\begin{abstract}
Today, the new development of world economy has promoted the new development of vocational education. Higher vocational education in developed countries and regions shows the tendencies of integrating higher vocational education with regular higher education, focusing on students' comprehensive ability, and strengthening practical training, continuous improvement of quality assurance system and timely application of new technologies. These trends provide enlightenments for the development of higher vocational education in China. On the basis of summarizing these tendencies, this paper discusses the path of developing higher vocational education in China.
\end{abstract}

\section{The Development Trend of Higher Education in Developed Countries and Regions}

In recent years, with the new development of world economy and technology, the development of higher vocational education in developed countries and regions has shown some new tendencies.

\subsection{The level of vocational education is upgraded; vocational education is integrated with} regular higher education

Vertically, occupational education in the world shows the development trend of "transformation from a fixed level to ascending levels". Vocational education is not limited in junior colleges. For instance, in France there are three levels of vocational education: junior college, undergraduate students and graduate students. In Britain there are two higher vocational education systems. One is the two-year diploma course; and the other is the four-year degree course. The United States cultivates professional masters major in nursing and social work. In Australia, vocational education and training are extended from high schools to graduate colleges. These communication and connections extend occupation education to a higher level, and make the vocational education adapt to economic development, meet the society's requirements on various types of vocational personnel, as well as students' needs of further education and employment. [1] Occupation education has transformed from "the terminal of education" to a stage in lifelong education.

Horizontally, higher vocational education is connected with undergraduate and post undergraduate education. A "cross bridge" multi-storey system, in which students' credits can be transferred, is established. For example, in Australian Technical and Further Education institutions (TAFE), students can go to study at universities after they get TAFE certificate, or obtain corresponding degree through cooperation programs with universities. The qualification education in Australia includes 6 levels: specialist diploma, bachelor degree, graduate certificate, graduate diploma, master degree and a doctorate degree. Among them, the first two "qualifications" or levels, namely vocational education "specialist diploma" is equal to the qualification of "higher education advanced diploma". [2] Graduates of vocational colleges in Germany can get master diploma like graduates of comprehensive universities; excellent graduates can even study for their doctorate degree.

\subsection{Curriculum objectives are "ability oriented" and focus on students' comprehensive ability}

Compared with the discipline-based standards of colleges, enterprises advocate ability-oriented standards. The ability of employees means their observed and measurable activities or actions which are related to their jobs. Their abilities are tested through task skill lists, and the course development 
is the study of a series of isolated task skills. On that basis, developed countries emphasize more on following aspects. First is overall capacity. For example, a number of business management schools in the United States identify individual qualities of successful managers, and develop courses based on these abilities. Second is key ability. Dries Mertens, a German scholar puts forward that we should cultivate the key ability of students, which means their abilities to adapt to changes in occupation. Third is comprehensive ability. It is considered that professional abilities should include the ability of applying basic principles and complex techniques independently, as well as the abilities of analyzing, judging, designing, planning, executing and evaluating. Professional abilities also include the ability of acting according to circumstances, and the ability of getting along with other people in the working environment. [3] Above non-technical abilities are considered to be crucial in the occupational career of students. American scholars believe that non-technical abilities refer to learning ability, academic and technological ability, communication adaptability, personal development, team development, team effectiveness and influence. In Australia, non non-technical abilities include communication skills, joint operation skills, problem solving skills, initiative and enterprising spirit, planning and organizing ability, self-management ability, learning ability and technical ability. [4]

Vocational education curriculum reform in developed countries also shows the trend of integrity. More and more emphases are placed on the cultivation of extensive adaptability and sustainable development of abilities. Generally, modular and integrated courses which are different from disciplines and branches courses are adopted. In 1990s of Germany, a new dual mode of curriculum, namely the learning field curriculum, came into existence. Learning field curriculum "is a kind of curriculum mode which takes the career actions as the object, takes the projects as the carrier, guided by the complete work process of business and working activities, and combine basic knowledge and professional skills reasonably into one system". [5]

\subsection{The cooperation between school and enterprise is diversified; practical training is strengthened}

The governments of all countries have made unremitting efforts to promote the cooperation between schools and enterprises. The United States government has formulated a series of laws and regulations, such as the Perkins Act, to promote cooperation between schools and enterprises. At the turn of the century, authority in France formulated the Charter of Vocational Education in Twenty-first Century, and decided to set up a dialogue mechanism between vocational education and the economic field, in order to strengthen the alternating teaching of work and study, and the training of vocational school teachers. The United Kingdom proposed that the representatives of business leaders and local entrepreneurs should occupy $2 / 3$ in central and local vocational education management institutions, so as to enhance the participation of enterprises in vocational education. Germany once stayed enforcement of the Enterprise Teacher Qualification Ordinance, stipulated that business teachers only require basic qualification of education enterprises on "hardware", so as to enhance the enthusiasm of educational enterprises. [6]

The higher vocational education in developed countries pays great attention to practical training and the combination of production and learning. In Germany, most students of occupational schools are required to spend $2 / 3$ of their time in enterprise training. A "sandwich" curriculum is implemented in polytechnics of Britain. "Dual" courses adopt the model of theoretical and practical courses combination. All engineer training courses should include internships. In DACUM curriculum developed by Canada, industry experts play an important role in curriculum development. They develop industry-oriented curriculum, analyze abilities required by all kinds of occupation scientifically, and propose curriculum standard accordingly, in order to ensure students' abilities meet the requirements of industries. [7] Higher vocational colleges and enterprises have gradually formed contractual relationship in the aspect of education quality assurance; they actively invite senior industry insiders to participate in the process of content and quality control of vocational education.

\subsection{The quality assurance system of higher vocational education is continuously improved}

Vocational education in developed countries has a relatively perfect quality guarantee system and a strict professional qualification certificate system. The success of Australian TAFE project lies in its 
perfect qualification certificate framework. The technical qualification certification in South Korea has enjoyed a high reputation in the world. Britain has all kinds of national and regional certificates; all professions and trades have corresponding qualification certificates. The industry believes and acknowledges the validity of these certificates, and the entire certification process is fairly standard. In the past ten years, the number of British invigilators who work outside school has increased rapidly, and the proportion of practitioners is getting higher and higher. [8]

In various countries, the unified and standardized quality assurance framework has become an important tool and method to ensure the quality of vocational education and training. For instance in 2009, the EU Education Council implemented the Common Quality Assurance Framework (CQAF) to encourage actions and promote cooperation of more countries and regions. The contents of CQAF include quality mode, evaluation mode, monitoring system and measurement tool. There are five steps: plan, implementation, evaluation, inspection and improvement, as well as methodology. More detailed criteria for specific indicators are set for each step. Through the establishment of quality assurance principles, as well as the credit transfer and accumulation system, CQAF establish a qualification certificate system and create mutual measurement tools between different countries and industry sectors. It is an index system which helps member states to monitor and evaluate to their own systems, improve the qualification certificate transparency, and strengthen the conversion of learning results.

\subsection{Educators pay attention to the application of information technology and other new technologies}

In order to meet the challenges of globalization and information technology, all countries have brought modern science and technology into the field of higher vocational education. In recent years, Germany began to carry out network higher vocational education. The Federal Ministry of Education and Research allocated special funds to promote the popularity of online vocational education. Deutsche Telecom has invested heavily to launch a free Internet program for 44 thousand schools across the country. All sectors of society in Germany also increase efforts in network platform; online education related to vocational training, adult education, continuing education and education on job changing is booming.

The E-learning Action Plan of European Commission, the Resolution on E-learning of the EU Council, and strategic documents about knowledge society of the European Union, reflect EU's strong intentions and efforts to make full use of the new information and communication technology (ICT). In the 2010 Education and Training Program, the EU emphasizes key capabilities required by the knowledge-based society. ICT is widely applied in vocational education. It is mainly used in links of teaching, management, communication, curriculum development, evaluation, career education and employment. It will be applied into other fields and promotes the development of higher vocational education to a greater extent. [9]

\section{Enlightenment for the Reform and Development of Higher Vocational Education in China}

\subsection{Improving the level of vocational education, and promoting communication between higher vocational education and regular higher education}

At present, junior college is the mainstream of higher vocational education in our country. It is still difficult to establish an upward higher vocational education system with ascending levels and can bridge the gap between higher vocational education and regular higher education. We should learn from developed countries and Taiwan, trying to meet the requirements of upgrading industries on highly skilled talents. We can adopt national model vocational colleges as pilots, and establish a complete vocational education system including undergraduate and postgraduate training. We should also set up a specialized examination for students who want to upgrade from junior college students to university students, unblock the path for students' promotion to ordinary academic universities, establish applied graduate degree projects in regular undergraduate colleges, and build an overpass for training highly skilled applied talents. 


\subsection{Teaching ability-oriented curriculum and cultivating students' comprehensive ability}

Currently theory-based teaching content of higher vocational education should be changed; a "dual" system of occupation education which takes job requirements as training objectives should be established. Technical grade standards should become the training objectives; teaching contents should be constructed correspondingly. Advanced technology and working organization models require high level expertise formed on the basis of high-level knowledge in specific areas, and even cross areas. Our country should take the advantages of Cluster Concept Program, including multiple selection, knowledge and technology convergence, as well as facing future. Learners should become "professional personnel" with comprehensive abilities and are able to deal with uncertainties successfully. A lifelong learning occupation education and training system should be established.

\subsection{Speeding up the legislation of vocational education and promoting the deep cooperation between schools and enterprises}

The government should become the dominant power in stakeholder partnerships of occupation education. The government should speed up the revision of laws and regulations on occupation education, and establish specific school enterprise cooperation procedures. By providing legal framework and policy support for the cooperation between schools and enterprises, the rights and obligations of schools, enterprises and students in the cooperation relationship can be identified. According to the target of "dual" system and school-enterprise cooperation, the management system of occupation education should be integrated and improved. With the cooperation of education department, economic department and labor department, enterprises can give full play to their functions in improving training standards, promoting curriculum reform and participating in practical training. Thus, the school enterprise cooperation can develop in depth.

\subsection{Establishing a quality assurance system to promote the continuous development of higher vocational education}

Learning from qualifications frameworks of developed countries, we can establish a rigorous, authoritative industry qualification certificate system with specific standards. Enterprises and industries should play the leading role in the formulating and evaluation of qualification certificates. The qualification certification system can play a key role in guaranteeing the quality of education. Teaching staff construction is the key to ensure the quality of education. We should learn experiences from developed countries, especially the experience of training and hiring "double-professionallytitled teachers" in Germany. College and university teachers should strengthen practice and be trained to achieve the requirement of "double-professionally- titled teachers". High level enterprise technical personnel can be hired as part-time teachers, in order to solve the problem of faculty deficiency.

\subsection{Paying attention to the application of new technology, such as the information network technology in the teaching process}

Following the development trend of "industrial manufacturing 4.0" and Internet technology, we should strengthen the technical education on high-tech industry and intelligent manufacturing, and improve students' capabilities on information technology. Digital campus should be constructed; school management should be improved by using information technology. Strengthening the communication between schools, enterprises and industries on Internet platform, information technology can be applied in information gathering and feedback, as well as the promotion of school-enterprise cooperation. Advanced information technology, such as simulation teaching should be actively used to improve the efficiency of daily teaching and training courses. We should strengthen the role of "e learning action plan" in students' independent learning and lifelong education projects. We should carry out higher vocational education and vocational training on the basis of network platform on distance education, and expand the reach of higher vocational education and training. 


\section{References}

[1] Z.W. Peng, The development trend of the higher vocational education system in major developed countries, J. The Science of Leadership Forum. 18 (2014).

[2] D.Y. Jiang, Z.R. Wang, Q.Q. Wu, D. Chen, Phenomena and principles in development trend of occupation education in contemporary world (two), J. Chinese Vocational and Technical Education. 21 (2012).

[3][8] X.Y. Ji, L.L. Zhang, X.M. Ni, Development trend of higher occupation education concept and mode in western countries, J. Vocational \& Technical Education Forum. 4 (2005).

[4][9] L.H. Ma, The new development trend of higher vocational education in the world, J. Education and Vocation. 27 (2009).

[5] X.J. Wu, D.Y. Zhu, Y. Hou, Comparative study on the development of occupation education curriculum in Australia, Germany and Canada, J. Journal of Chengdu Aeronautic Polytechnic. 4 (2009).

[6] D.Y. Jiang, Z.R. Wang, Q.Q. Wu, D. Chen, Phenomena and principles in development trend of occupation education in contemporary world (three), J. Chinese Vocational and Technical Education. 24 (2012).

[7] Y.W. Liu, the development trend of vocational education curriculum model at home and abroad, J. Continue Education Research. 2 (2011). 